\title{
ONESNAŽENOST ZRAKA V LJUBLJANI. KONCENTRACIJE DUŠIKOVIH OKSIDOV, OZONA, BENZENA IN ČRNEGA OGLJIKA V LETIH 2013 IN 2014
}

\author{
Matej Ogrin, Katja Vintar Mally, Anton Planin- \\ šek, Griša Močnik, Luka Drinovec, Asta Grego- \\ rič in Ivan Iskra: Onesnaženost zraka v Ljubljani. \\ Koncentracije dušikovih oksidov, ozona, benze- \\ na in črnega ogljika v letih 2013 in 20l4. Zbirka \\ GeograFF 14. Znanstvena založba Filozofske fa- \\ kultete Univerze v Ljubljani in Oddelek za geo- \\ grafijo, I 23 str. Ljubljana, 2014
}

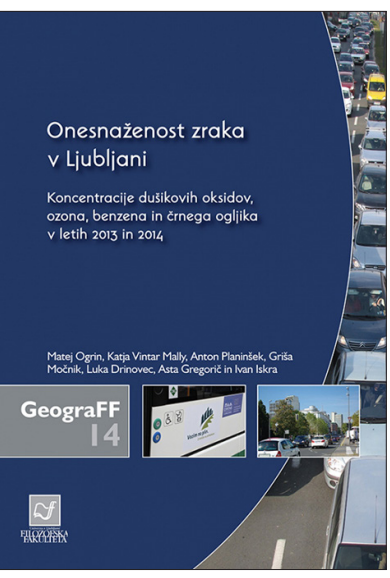

Osnova za znanstveno monografijo skupine avtorjev Onesnaženost zraka v Ljubljani, s podnaslovom Koncentracije dušikovih oksidov, ozona, benzena in črnega ogljika v letih 2013 in 2014, je bil raziskovalni projekt Toplotni otok mesta (UHI), katerega naročnik je bila Mestna občina Ljubljana. Knjiga se posveča prometnemu onesnaževanju ozračja v Ljubljani znotraj avtocestnega obroča ter predstavlja nadaljevanje in nadgradnjo projekta iz leta 2005/2006 in knjige Prometno onesnaževanje ozračja z dušikovim dioksidom v Ljubljani (GeograFF 1) iz leta 2008.

Monografija je razdeljena na devet temeljnih poglavij. V začetnih dveh je pregled dosedanjih raziskav in literature o onesnaženosti zraka v Sloveniji in Ljubljani ter razvoja slovenske zakonodaje na področju varstva zraka. Sledi metodološko poglavje, v katerem so predstavljene prednosti in slabosti uporabe difuzivnih (pasivnih) vzorčevalnikov. Difuzivni vzorčevalniki so bili uporabljeni tudi v raziskavi leta 2005/2006, kar omogoča primerljivost rezultatov s časom pred skoraj desetimi leti. V vmesnem obdobju so bili v Ljubljani izvedeni nekateri ukrepi v smeri umirjanja prometa in podpore trajnostnim načinom mobilnosti, zato rezultati raziskave nudijo tudi možnost ocene učinkovitosti teh ukrepov. Poglavitne prednosti difuzivnih vzorčevalnikov so preprostost in praktičnost uporabe ter nizka cena, kar omogoča gosto prostorsko mrežo meritev in temu primerno gostoto podatkov za prostorski prikaz onesnaženosti zraka. Izvajalci projekta (Oddelek za geografijo FF UL v sodelovanju z Agencijo RS za okolje) so vzorčevalnike namestili v tri tipe mestnega prostora: ob cestne koridorje, $\mathrm{v}$ odprt prostor ob cestah in $\mathrm{v}$ urbano ozadje ter dodatno na prečne profile ob cestah. Meritve profilov koncentracij so omogočile ugotavljanje spreminjanja koncentracij onesnaževal z oddaljenostjo od ceste. Ker so koncentracije onesnaževal v zraku zelo odvisne od tipa vremena, so vremenske razmere, ločeno za zimsko in poletno merilno obdobje, prikazane v posebnem poglavju. Žal vreme v času izpostavljenosti vzorčevalnikov ni bilo najbolj tipično za oba letna časa, 
saj je bilo stabilnega, anticiklonalnega vremena s temperaturnim obratom, ko je kakovost zraka najslabša, zelo malo.

Osrednja štiri poglavja prinašajo rezultate meritev dušikovega dioksida in ozona $\mathrm{v}$ poletnem merilnem obdobju ter dušikovega dioksida, benzena in črnega ogljika $\mathrm{v}$ zimskem obdobju. Meritve črnega ogljika (saje) in vrednotenje rezultatov te raziskave so opravili raziskovalci podjetja Aerosol in Laboratorija za raziskave v okolju Univerze v Novi Gorici. Posebej so predstavljeni rezultati primerjave poletne in zimske onesnaženosti zraka z dušikovim dioksidom. Primerjava omogoča boljše razumevanje dinamike onesnaženosti skozi leto, pri čemer velja, da so zimske razmere za kakovost zraka zaradi nižjih samočistilnih sposobnosti in večjih obremenitev v splošnem najmanj ugodne. $Z$ uporabo rezultatov poletnih in zimskih meritev so avtorji ocenili tudi letno stopnjo onesnaženosti zraka z dušikovim dioksidom v Ljubljani. Ocena je bila narejena za merilna mesta, kjer so potekale meritve $v$ obeh letnih časih. Pri njenem izračunu so bile uporabljene letne koncentracije, ki jih je izmerila samodejna merilna naprava ARSO.

Poletne meritve so v določenih mestnih predelih pokazale veliko onesnaženost zraka, pri čemer se onesnažene lokacije za obe onesnaževali (ogljikov dioksid in ozon) izključujejo. Visoke koncentracije dušikovega dioksida v središču mesta, zlasti v koridorjih in neposredno ob cestah, nakazujejo nujnost omejevanja prometa v mestnem središču. Pri poletnih meritvah ozona so bile najvišje koncentracije v nekaterih parkih in drugih mestnih območjih miru, kar je posledica odsotnosti dušikovega monoksida, ki razkraja ozon. V zimskem obdobju so ugotovili visoke koncentracije dušikovega dioksida v urbanem ozadju, prav tako v odprtem prostoru ob cestah in tudi v cestnih koridorjih. Ker so bile vremenske razmere netipične, z večjim mešanjem ozračja, avtorji sklepajo, da bi bilo onesnaženje ob ustaljenem, mirnem anticiklonalnem vremenu še večje. Precejšnja splošna onesnaženost zraka z dušikovim dioksidom nad Ljubljano pozimi, tudi zaradi izpustov iz kurišč, opozarja na nujnost sistematičnega ter podrobnega spremljanja celotne problematike. Meritve opozarjajo tudi na visoke zimske koncentracije v koridorju Slovenske ceste v središču Ljubljane, kjer je bil promet že omejen. To je jasno sporočilo načrtovalcem prometa in rabe prostora $v$ mestu, da se mora modernizacija javnega potniškega prometa nadaljevati, dejavnosti v in ob cestnem koridorju Slovenske ceste pa načrtovati tako, da bo imel negativen vpliv prekomerne onesnaženosti v koridorju čim manjši učinek. Meritve profilov koncentracij ob cestah nakazujejo, da najbolj onesnažen pas ob cestah ne seže dlje od $80 \mathrm{~m}$ in da se onesnaženost $\mathrm{z}$ oddaljenostjo od prometnic razmeroma hitro zmanjšuje.

$\mathrm{V}$ primerjavi $\mathrm{z}$ dušikovim dioksidom onesnaženost $\mathrm{z}$ benzenom $\mathrm{v}$ Ljubljani ni problematična. Bolj pereče so lahko koncentracije črnega ogljika, še posebej v stabilnih vremenskih pogojih, ko je mešanje ozračja in redčenje emisij manjše. Zanimivo pri onesnaženju s črnim ogljikom je, da kurišča prispevajo k enakomerni onesnaženosti v prostoru, promet pa to onesnaženost lokalno precej poveča.

$\mathrm{Z}$ vidika uporabnikov, to je Mestne občine Ljubljana ter njenih načrtovalcev urbanistične in prometne ureditve, so dragocene sklepne ugotovitve. Tu avtorji, izhajajoč iz rezultatov raziskave, opozarjajo na najbolj pereče probleme prometnega 
onesnaževanja ozračja v Ljubljani. Ugotavljajo, da so dosedanji ukrepi mestnih oblasti znanilci prebujanja na področju trajnostnega prometa, vendar pogrešajo usklajene ukrepe, ki bi pozitivne učinke povezali in okrepili. Kot integralen ukrep za zmanjšanje prometnega obremenjevanja in izboljšanje kakovosti življenja predlagajo trajnostno prometno načrtovanje. Predlagajo, da naj bi to postalo osnova prometnega načrtovanja tudi v ostalih slovenskih mestih.

Darko Ogrin 